Authors' pre-print version (i.e., final draft pre-refereeing)

To be published as:

Tutenel, P., Ramaekers, S., Heylighen, A., Understanding children's spatiality in cancer care environments: Untangling everyday practices around an IV-stand in a paediatric day-care ward, Health and Place

Please refer to the publisher's final version. 


\title{
Understanding children's spatiality in cancer care environments: Untangling everyday practices around an IV-stand in a paediatric day-care ward
}

Piet Tutenel, Stefan Ramaekers, Ann Heylighen

\begin{abstract}
Since the turn of the 21st century we see a renewed interest in the impact of hospital environments on children's well-being. In this article, we study the spatiality of children affected by cancer, i.e., their encounters with the day-care ward they are situated in. First we elaborate on these encounters through Schatzki's practice theory and Gibson's theory of affordances. Then we clarify our thinking in a case study and turn as empirical focus to a 'thing', an intravenous-pump and stand (IV-stand). The data used are field notes and videos shot by two children in a day-care ward, tinged with examples from literature and coincidental encounters with the IV-stand. Through carefully untangling everyday practices around the IVstand, we show their complexity and offer a more nuanced understanding of child-friendly environments.
\end{abstract}

Keywords: affordance, built care environments, children and youth, practice theory, spatiality

\section{Introduction}

Since the turn of the 21st century the impact of hospital environments on children's well-being receives a heightened interest from policy, research and practice across a range of disciplines. This interest is not a new phenomenon. Throughout history designers and care workers alike have been aiming to 'humanise' (Bates, 2018) and 'normalise' (Adams, 2017) hospitals in general, and children's hospital environments in particular (Van der Horst and Van der Veer, 2009). Of course, hospital design is also determined by larger societal and architectural trends (Adams et al., 2010; Kearns and Barnett, 2000). Physical features of the hospital environment have always been interwoven with changing discourses on and practices surrounding care, disease, domesticity and childhood (Adams, 2008; James and Curtis, 2012; Kozlovsky, 2013, 2015; Prior, 1988; Sloane, 2008).

What distinguishes the present period, however, is the shift to integrate 'the view of the child' in research, design and policy on/of (care) environments (Holloway and Valentine, 2000): (critical) reflections on spatial aspects and built care environments of childhood are complemented with children and young people's experiences of these environments (e.g., Adams et al., 2009; Epstein et al., 2006). Birch et al.'s (2007) study was one of the first to explore how children experience hospital spaces with the aim to inform the design of child-friendly hospital environments. Following in these footsteps researchers started to consider children as research participants in order to explore their perspectives on and affective relationships with the built hospital environment (Bishop, 2009, 2010; Heath et al., 2015; Lambert et al., 2014ab; NortonWestwood, 2012; Peeters et al., 2018; Verschoren et al., 2015; Water et al., 2017).

People experience the environment, however, from within - that is, as part of it (cf. Ingold, 2000; Leder Mackley et al., 2015). This way of thinking about space has recently been advanced by posthuman or sociomaterial approaches in, e.g., new childhood sociological and geographical approaches (Holloway et al., 2018). Through notions such as 'encounter', 'network', and 'gathering', these approaches direct attention to how human and other-than-human agents or entities mutually constitute each other in and through 
everyday practices. This allows researchers not only to study practices not only from the perspective of human agents, their intentions, and the ways in which they attribute meaning to the world, but also to focus on how other-than-human entities, i.e. toys (Woodyer, 2008), newspapers (Noens and Ramaekers, 2015), animals (Malone, 2017), and stones (Rautio, 2013) contribute to the constitution of such practices. We can call these entities 'nodes' (cf. Preda, 1999): they can be understood as those focal points that simultaneously gather humans and other-than-humans, and around which humans and other-thanhumans are gathered. These entities are not necessarily of interest from the perspective of the humans involved, nor are they the most determining. Nevertheless, they play a part in the existence of ongoing arrangements and practices. These approaches have already been used in research on children's everyday practices in contexts such as homes (Leder Mackley et al., 2015; Wilson et al., 2012), museums (Birch, 2018; Macrae et al., 2017), and (outdoor) educational settings (Änggård, 2015; Merewether, 2019). In research on children's hospital environments these approaches are yet to be explored.

To complement and reframe current research on children's experiences of the built care environment, this article focuses on everyday practices as shaping and as part of hospital spaces (cf. Adams et al. 2010; Zitzelsberger et al., 2014). Examining spatiality as the encounters between children and the worlds they are situated in offers new perspectives on how spaces affect and shape experiences and vice versa (Hackett et al., 2015). This involves exploring the doings (Schatzki, 2002) by which human and other-than-human entities participate in practices.

Our overall aim is twofold: (1) to refine our conceptual and methodological framework to research children's spatiality in cancer care environments; (2) to broaden our understanding of child-friendly care environments by exploring everyday practices and arrangements mostly left unnoticed.

We elaborate this in two parts: The first part of this article explores Schatzki's (2002) theory of practice and Gibson's (1979) theory of affordances. These approaches can help focus more explicitly on specific arrangements of humans and other-than-humans within everyday practices. The second part of this article further clarifies our way of thinking in a case study. In exploring everyday practices in a paediatric day-care ward, we use an intravenous pump and stand (IV-stand) as empirical focus.

\section{Part I: Conceptual framework}

Socio-material approaches start from the idea that social practices are constituted by human and otherthan-human entities. Rather than locating agency (exclusively) in human individuals, social practices are understood (cf. supra) as forms of gatherings of humans and other-than-humans (Noens and Ramaekers, 2017). Schatzki's socio-material stance is interesting for our study as it proposes a site ontology that considers not only practices but also (im-)material arrangements (orders) as crucial parts of social reality (Caldwell, 2012). A site (Schatzki, 2002, pp. 64) is a specific understanding of context: it combines the idea that a context helps to give form to what makes sense to do with the idea that doings help to give intrinsically form to a specific context.

Practices, according to Schatzki (2002), are open and spatially, temporally dispersed sets of doings and sayings organised by common understandings, teleology (ends and tasks), and rules. Doings are occurrences in the continuous flow of events that befall humans and other-than-humans (Schatzki, 2002). Doings can always be assigned to someone or something, but what is done can be determined by the observer only after it has been performed. This implies that there remains always an important degree of uncertainty for the observer, because the observed doing can always continue in several directions - it has a kind of 'indeterminacy' (Schatzki, 2012, p 19). 
Material arrangements (orders) are made up by material entities that are interconnected in specific ways. The entities that make up arrangements can be segregated into four types: humans, artifacts, organisms, and (other) things of nature (Schatzki, 2002). Practices and material arrangements are inevitably entangled. Practices contribute to creating material arrangements; at the same time they are carried out by material arrangements and transpire through them.

Schatzki distinguishes 'lived space' from 'objective space' and calls the former spatiality (cf. Heidegger's Räumlichkeit). He conceptualizes spatiality as 'the world around (an actor) in its pertinence to and involvement in human activity' (Schatzki, 2009, p. 36). This world is involved in human activity by offering a platform for, and comprising entities that have places in, human activities. Spatiality, as a result, embraces a variety of places and paths that are anchored in material arrangements and gain their specific relevance only within practice(s) (Schatzki, 1991). A place is a place to X, e.g., a bed is a place to sleep, a bus stop a place to catch the bus. Paths are a particular type of place: places on which to reach $Y$ from $X$ (routes). Beyond its physical attributes, the built environment is part of social reality comprised of an organized nexus of places and paths. Studying practices thus becomes in fact a means of studying spatiality.

Since the social and the material are closely intertwined, it is important to study how they perform together. Following Schatzki: 'Because the relationship between practices and material entities is so intimate, I believe that the notion of a bundle of practices and material arrangements is fundamental to analyzing human life' (Schatzki, 2002, p. 106).

In order to study and conceptualize the constitutive encounter of the social and the material in everyday life, two widely influential approaches have been developed: the script approach and the affordance approach (Jarzabkowski and Pinch, 2013, p. 581). We focus in this article on the affordance approach as it is more frequently used to research and design the built environment (Baumers and Heylighen, 2010; Koutamanis, 2006; Maier and Fadel, 2009; Rietveld and Rietveld, 2011). Gibson developed his 'theory of affordances' in his seminal work 'The ecological approach to visual perception' (1979). 'An affordance is what the environment offers the animal, what it provides or furnishes, either for good or ill' (Gibson, 1979, p. 127). Gibson's notion of affordance is complex and understood in many different ways, but there is nevertheless widespread agreement that affordances are to be understood as possibilities for action provided to an animal by the environment - by the substances, surfaces, objects, and other living creatures that surround the animal (Chemero, 2003). Gibson (1979, p. 129) extends that:

affordances of the environment are in a sense objective, real, and physical, unlike values and meanings, which are often supposed to be subjective, phenomenal, and mental. An affordance is neither an objective property nor a subjective property; or it is both if you like. An affordance cuts across the dichotomy of subjective-objective and helps to understand its inadequacy. It is equally a fact of the environment and a fact of behavior. It is both physical and psychical, yet neither.

Gibson's concept of affordances can be seen as an attempt to undermine the traditional dualism of the objective and subjective (Costall, 2012).

The notion of affordance has given rise to many theoretical debates (Lindberg and Lyytinen, 2013), e.g., between those who think affordances as available resources (e.g., Reed, 1996) and those who believe they are relational (e.g., Chemero, 2003). A recurring critique of the affordance approach is that it tends 'to black box' social interactions within which activities are accomplished in order to focus on the objects themselves (e.g., Jarzabkowski and Pinch, 2013). Hence, the contextually situated nature of these interactions is 
overlooked. Rietveld and colleagues (Rietveld and Kiverstein, 2014; Van Dijk and Rietveld, 2017), however, conceptualize affordances as being both relational and a resource by understanding them as situated: affordances are always already situated in the socio-material practices that make up our human form of life. They define an affordance as: 'a relation between an aspect of the socio-material environment in flux and an ability available in a form of life' (Van Dijck and Rietveld, 2017, p. 5).

Van Dijk and Rietveld (2017) take three different perspectives on affordances in a situation and use the metaphor of zooming in and out to explain how socio-materiality shows up therein (see also Nicolini, 2009). To start with, zooming out shows a landscape of affordances offered by the socio-material environment. Think of a zoomed-out perspective on a city park, which would allow noticing patterns. Second, zooming in shows a concrete situation unfolding from the perspective of an observer (e.g., a researcher), who focuses on an individual coordinating with affordances offered by things and other people situated in this landscape. The third perspective originates from within an unfolding activity. Making sense of a situation involves different perspectives: zooming in highlights the unfolding dynamics, but obscures persistent practices and regularities; zooming out obscures that the socio-materiality of the landscape of affordances is in flux.

These theoretical approaches offer an interesting lens for our research. They guide us as to how children's spatiality in cancer care environments can be understood through studying practices, and provide insights into how these practices can be explored. In the next part of this article we present a concrete analysis of a case to further clarify our thinking.

\section{Part II: The case around an IV-stand in a paediatric day-care ward}

A case study can be defined as the study of a case (a person, place, event), selected for its particularity, and bounded by physical, temporal, social/cultural, and conceptual features (Flyvbjerg, 2006; Yin, 2011). What we present is an instrumental case study (Baxter and Jack, 2008): it is used to provide insight into an issue or helps to refine a theory. It is thus not just an example of or to (cf. Mol, 2008).

We explore the IV-stand as a gathering node in the paediatric day-care ward (Fig. 1). The IV-stand consists of different parts: an infusion pump, a mobile stand (with handle), infusion bag(s), plastic tube(s), a cannula or a catheter. The IV-stand has been designed to induce fluids into human bodies in a safe and controlled way while the patient remains able to move about. It became part of medical practices around 1950 and has been used extensively ever since (Southorn and Nar, 2008). In contrast to others who explore the interrelations between materials and care in practice(s) (Parbhu et al., 2019; Water et al., 2018; Zitzelsberger et al., 2014; for an overview see, Buse et al., 2018), we understand the IV-stand and other medical materials also as mundane artifacts in the day-care ward - alongside (or in dialogue with) other artifacts. The IV-stand is as taken for granted in the hospital ward as a shopping cart is in a Western supermarket. 
Fig. 1 - Diagrammatic floor plan of the paediatric day-care ward (C) Laure Verschoren, 2014). The Lshaped ward is situated on the ground floor of a large-scale university hospital in Belgium. It is part of the paediatric hospital and the oldest building on the site, in use as of 1975. The modernist building is the result of a joint venture between a Belgian and a UK architecture firm. One of the UK architects was involved in the seminal study 'Children in hospital: Studies in planning' (Nuffield Foundation, 1963). During the period of the fieldwork the setting was organized as follows: W: Waiting area; C: Consultation room; P: Patient room; S: Staff room

W1: waiting nook near the entrance; W2: waiting/play space; C1-2: consultation rooms; P1-2: patient rooms; P3-5: glass cubicle isolationrooms; S1: staff area/the curved desk delineates patient and staff spaces; 52 : head nurse's office and staff room/kitchen

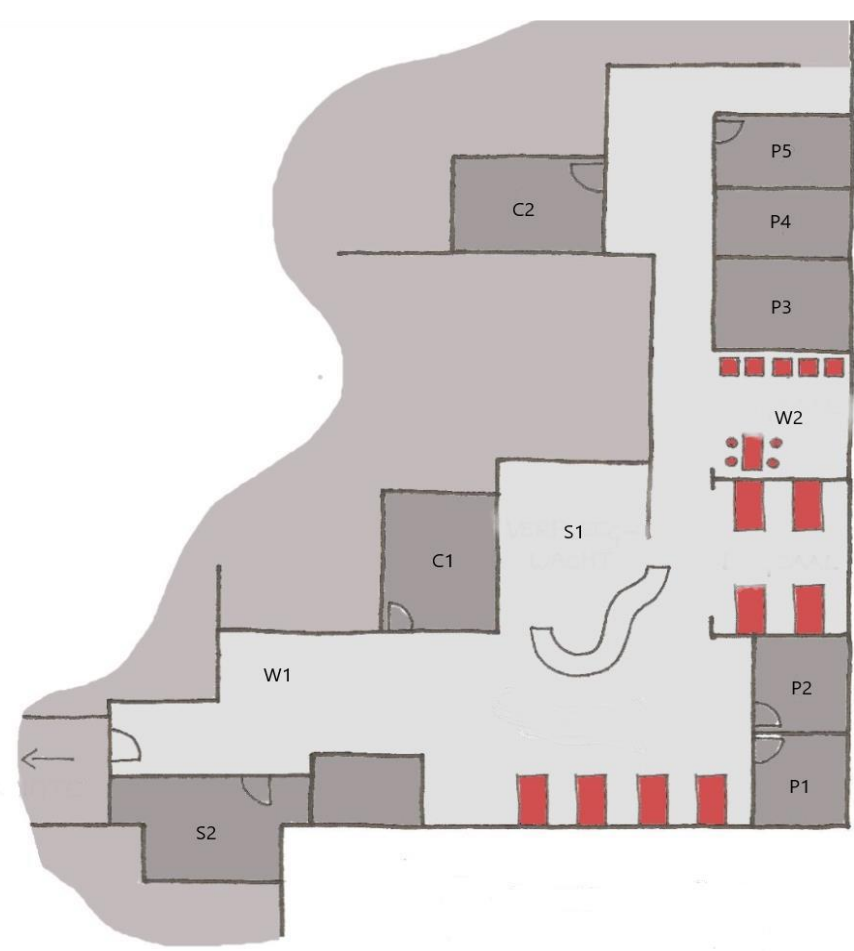

The IV-stand was not an object that mattered from the start of the study. We did not intentionally follow an IV-stand. Like in the studies mentioned earlier, it 'became notable' (Reh and Temel, 2014, p. 171) and found its way into the picture(s). What emerged unexpectedly (cf. Fayard and Weeks, 2007; Noens and Ramaekers, 2015) in the observations and led to our focus in this article, is the degree to which the children, caregivers and other adults interacted with the IV-stand. Had it been intentionally designed to afford social interaction rather than to induce medicine into bodies in a mobile way, it could hardly have succeeded better in the paediatric day-care ward.

In this case study we use different types of data. Foremost, we use data gathered during a pilot study. The pilot is part of a broader project which investigates the experiences of children and youth between 5 and 18 years old affected by cancer - and their siblings - and explores how these can inform the design of cancer care environments.

The data we start from are action camera-video images shot by two participating children (a boy and a girl, both 8 years old) and the first author (henceforth the researcher) during the pilot study. In addition, we use observational field notes collected by the researcher during the pilot study. Between April and June 2018, the researcher and the two children (and sometimes a (grand-)parent) met ten times at the day-care ward. Both participants were in an advanced treatment stage and thus used to visiting the paediatric ward. As the participants were expected to visit the ward for several hours up to three days per week (for their medical treatment, check-ups, etc.), appointments were scheduled during these moments to minimize extra burden. The meetings lasted between 20 minutes and 1,5 hours depending on the children's moods, energy level or therapeutic interventions necessary. The first time the researcher and children met was to discuss the research. Through conversations and small exercises they worked around the content of the research, what architects and designers do, what research is, and what researchers do. During the following meetings the children and researcher jointly filmed, edited, and discussed the images, constructing collaborative presentations of the paediatric day-care ward (Milstein, 2015). Rather than asking specific 
questions, they just started exploring (what goes on in) the ward through working with video (Pink, 2013; Tutenel et al., 2019). For this article we return to the unedited images as raw data - well aware, however, that raw data are always already cooked (Packer, 2011): rather than as something 'out there', waiting to be collected, analysed and represented from a distance, we understand data as constituted by what we are researching.

Next to analysing the images and field notes, we searched how the IV-stand is used/staged in hospital ethnographies, illness narratives, and studies in the sociology of health. Finally, we use as data also a more coincidental encounter with the IV-stand while watching the news.

We structure our analysis using the two theoretical approaches outlined above and three perspectives similar to those developed by Rietveld and colleagues $(2014 ; 2017)$. This brings into view the IV-stand as a gathering node around which the spatiality of the children involved in this study takes shape as a bundle of practices and material arrangements. We start our situating from a zoomed-out perspective stepwise zooming in.

a. The zoomed-out perspective: The IV-stand as backdrop to care

In the following paragraphs we explore the zoomed-out perspective through two examples: (1) how the IVstand is mentioned in research, and (2) how it features in a news item.

(1) In (hospital) ethnographies and illness narratives the IV-stand is often mentioned to provide a kind of background. It is a witness, but not of the silent kind as is clear in Walker's (2018) 'A family history of illness: Memory as medicine': 'As these last words left his lips, disappearing among the bells and peeps of finicky IV pumps, he rested his head against the brown vinyl reclining chair' (p. 94). In a study exploring how people proceed through cancer treatment, Overcash (2003, p. 179) starts Laura's story mentioning the IV-pole: 'Laura watched as the familiar clear liquid dripped from a transparent bag attached to the IV pole situated immediately overhead'. Heineman (2015), in her study on medicine and home life, also uses an IV-stand as frame: 'He was seated in a large reclining chair surrounded by an IV pole and several five-gallon-sized white plastic bags that quite literally were overflowing with medical supplies' (p. 33).

(2) A second example we found in a television news item on how the 'Gentse feesten'- a yearly festival in the city of Ghent (Belgium) - are celebrated in the paediatric hospital. The camera person used the IV-stand to focus the image, setting the scene for the viewers (Fig. 2). Should we erase the IV-stands from this image it would be much harder - almost impossible - to recognize the setting as care environment.

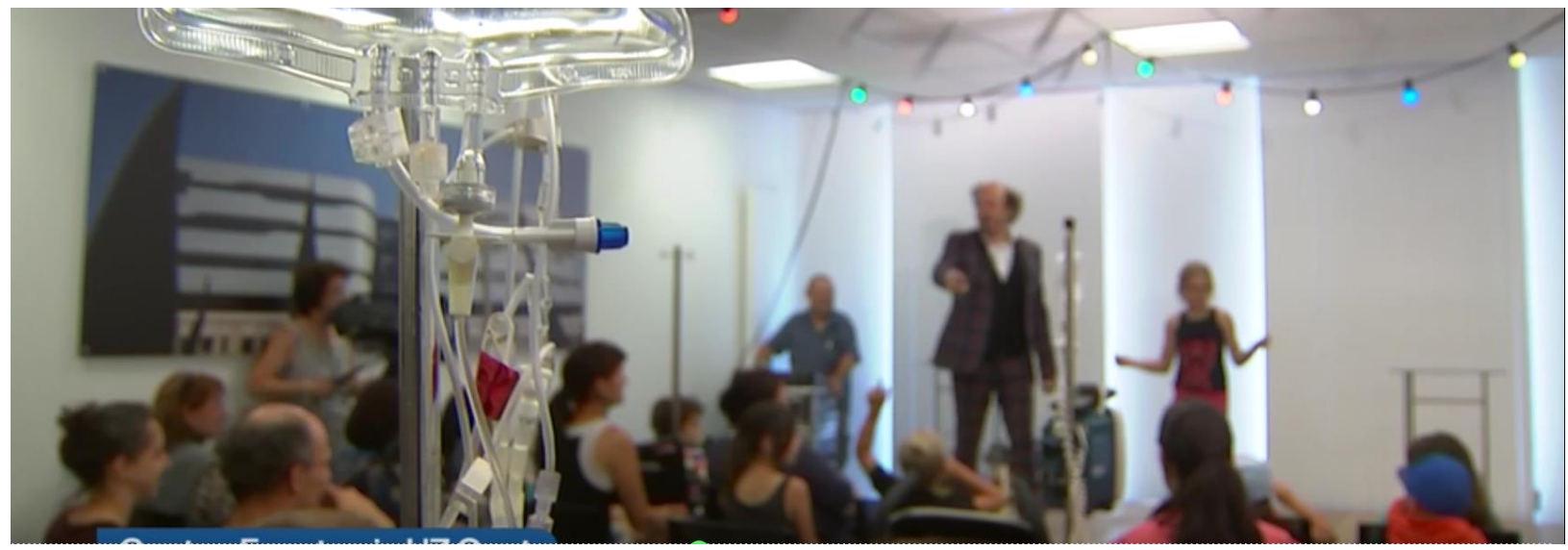

Fig. 2 -- Still frame taken from a news item on the Gentse Feesten. Retrieved from https://www.vrt.be/vrtnws/nl/ on July 162018. 
The zoomed-out perspective shows that in Western society today the IV-stand is an important artifact in practices of care. From this perspective the IV-stand is mostly just there. It affords recognisability because it is part of stable and persistent orders and practices. Before its introduction around 1950, people used other artifacts to provide a stage for care. These examples show how practice-place-object relations are always made rather than fixed, and therefore always open to future change. Following Schatzki, care practices and the material arrangements in and through which they transpire in Western society can be said to be understood as strongly anchored in the IV-stand. There is a shared or general understanding of how (or at least: 'that') this material object takes part in care practices.

\section{b. The observer's perspective: Practices around the IV-stand}

Whereas the first perspective helps to situate well-established practices within a care environment and the general understandings of objects like the IV-stand taking part therein, zooming in reveals a variety of ways in which it does so.

Most of the time the IV-stand is not interesting as such and the participants are indifferent about it. Their doings are of course influenced by how the IV-stand is present (attached to them) but it mainly attracts their attention when it annoys them, gets in the way of things or breaks down (cf. as in illness narratives: Frank, 2015; Lindberg and Walter, 2013; Von Eron Sherman, 2009). Still frames shot from the IV-stand (Fig. 3) show the IV-pump's beeping noise (ti-ta; ti-ta; ti-ta) interrupting music therapy on the hospital bed.

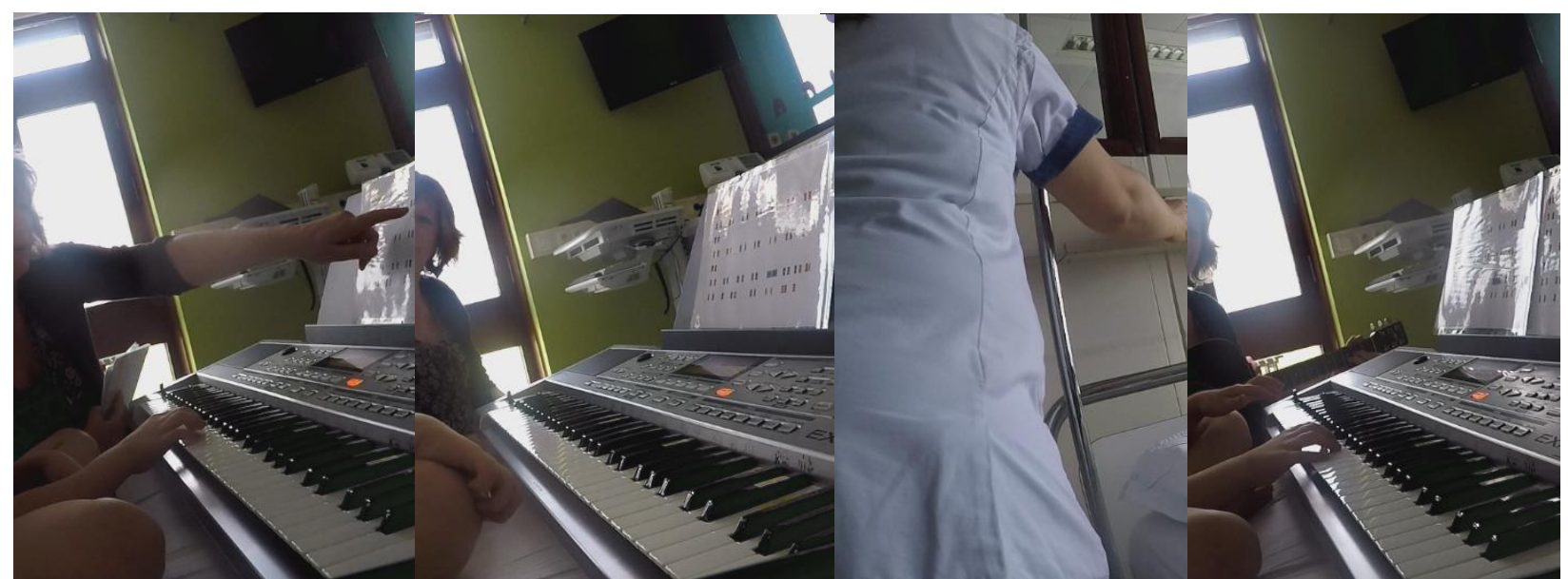

Fig. 3 -- Practicing the Pirates of the Caribbean theme song interrupted by the beeping IV-pump. "Let us start over, with all these interruptions...", the music therapist said after the IV-pump had been reset by a nurse. [see Fig. 1: P3]

Besides observing that the IV-stand is annoying and interrupting, this second perspective allows us to identify different practices by pointing at 'what' it is the IV-stand is intervening with. These are practices like moving about in the ward, playing the piano, resting, sleeping, watching TV, bathroom practices and engaging with parents and staff. During the pilot other practices the IVstand is involved in become noticeable (cf. Fig. 4 and 5): (everyday) medical practices (e.g., changing blood bags or rinsing), waiting, being on a smartphone, eating, reading, organized play

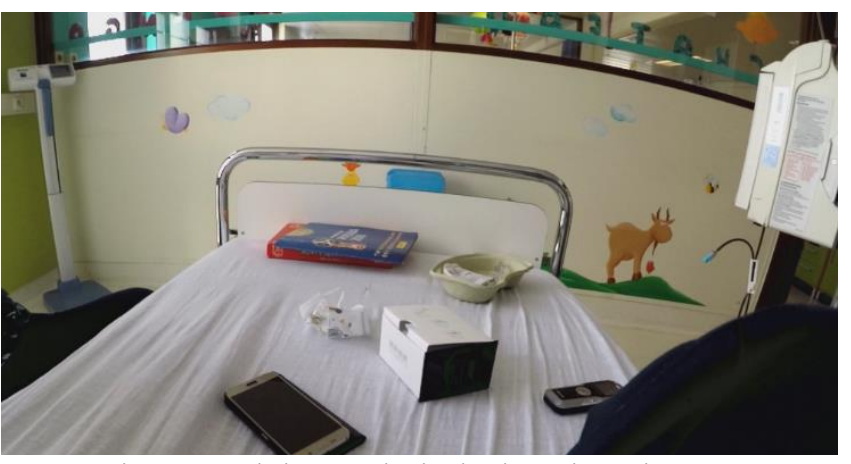

Fig. 4 -- The IV-stand close to the bed side in the isolation room. [see Fig. 1: P3] activities like drawing, and other education practices. The list is of course incomplete and in some practices 
the IV-stand is more directly involved than others. It affords stability to attach a camera to during research, but also support to lean on while having a conversation, or for young children, to stand on its foot, being moved around by their parents or caregivers. And at Christmas time it affords being decorated.

c. Within an unfolding activity: Exploring 'waiting practices' from the perspective of the IV-pump

While the second perspective allows to observe different practices and activities the IV-stand is involved in, the third one looks from within an unfolding activity, namely waiting in the waiting area of the day-care ward. We use waiting as an example because receiving (cancer) treatment in a hospital consists largely out of the things people do while waiting for or during treatment.

Researcher's consideration:

There are two waiting areas in this paediatric day-care ward (Fig. 1: W1-2). The first one is an open space (a nook) ( $4 \times 3 \mathrm{~m}$, more or less) close to the entrance. The second area is located in and near the play room around the corner of the L-shaped ward. The waiting nook where I was observing (Fig. 1: W1) during a morning shift contains three large sofa's, set up in a u-shape around a low table with colouring pages and some pencils, so children have something to do while waiting. Two mothers and two daughters - supposing this is their relation - were waiting. They were sitting there in silence. They were reading, scrolling their tablets, looking at cell phones, or just staring. The youngest girl was wearing pink headphones. From time to time she looked up, removed one of the shells and asked 'what'? 'I didn't say anything', the mother replied. The other girl was studying for her driver' s license while texting on her cellphone. After a short while another mother and daughter came and sat with us. The daughter immediately opened her laptop and put on her headphones. The mother started reading a fashion magazine. Now and then they lifted their heads to check the progress on the IV-drip.

At one moment an IV-pumps started beeping. 'Is it yours?', a mother asked. 'No', the daughter replied. 'No, it's mine', said the girl who was sitting in the opposite sofa. The conversation ended, people walked by and it seemed I was the only one who was confused by this shrieking sound. A nurse showed up a few minutes later. 'Oh, the battery is low and there is no wall outlet where you're sitting. That's such a big problem here. We'll have to move you'. Where I was sitting there was an available wall outlet. The girl stood up dragging the IV-pole behind her. We swapped places. 'Are you studying for your driver's license?', the nurse asked the other girl while plugging in the IV-pump.

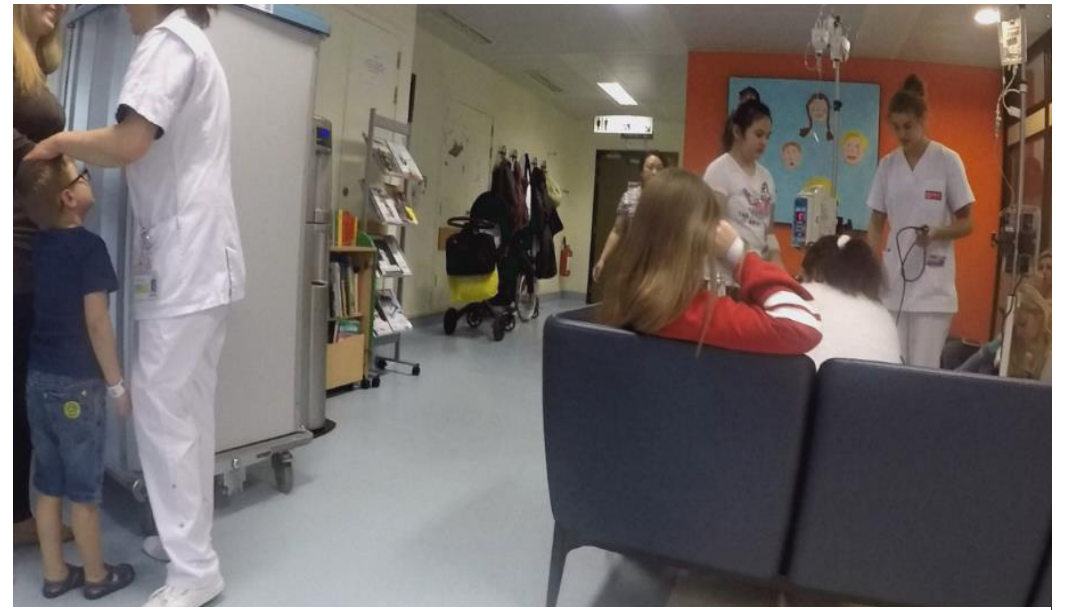

Fig. 5 -- Waiting in the hospital's paediatric day-care ward. [see Fig. 1: W1] This still frame captures a similar situation as the one described in the observational notes: A nurse apprentice holding the black connection wire while guiding a girl and her IV-stand towards an available wall outlet. The mother moving along with her. The girl in the white sweater in movement to switch seats and trying to avoid collision between her IV-stand and the other IV-stand. The girls seated in the right sofa gazing at what is going on. The girl in red pullover sitting in the sofa.

'Yes, theoretical exam in a few days', the girl said. 'Good luck with that, I had to take the exam several times before I passed', the nurse said smiling. 'So, that's that, it will probably not beep anymore. I'll come and check on you when it's time to rinse', she said, already on her way towards another beep. 
How might we understand this particular situation? The waiting room - like many other waiting rooms in this society - is recognizable as such (see Fig. 5): (untouched) books and informational leaflets, a coat rack at the entrance, a low table in the middle with colouring pages or used magazines, blue seats, and an orange wall with a playful painting to mark the space as waiting area for children. There is also a quite recognizable pattern and much regularity to be observed as part of this material arrangement. Children and parents are sitting in the sofa, reading, staring, looking at their mobile phones, opening laptops, and putting on headphones. While just sitting and waiting, most of them do not talk. Only from time to time they interact with one another, for example when making room on the sofa for other people.

These stable patterns of behaviour are sometimes disrupted by the IV-stand's doings, generating a more dynamic atmosphere. Talk is triggered about the IV-stand itself - 'I'm on my way', in reaction to a beeping IV-pump, 'still 10 minutes of rinsing', while staring at the drip timer, ...-and about other topics like obtaining a driver's license. Next to affording conversation along, the IV-stand makes people move closer to a wall outlet, swap places, lift up their feet, and direct attention to it. Of course other things happen: scanning patient ID bracelets, measuring blood pressure, drinking soda and eating crisps, tying shoelaces, getting a coffee from the thermos, getting called away for their doctor's appointment,... . But most of the events were (seemingly) steered by the IV-stand.

Within this particular unfolding situation we see the IV-stand afford what its designers intended: inducing fluids into bodies in a safe way, while the patient stays mobile. Asking for attention when something is wrong with the pump is also what it is designed to do. As shown, what the IV-stand affords extends beyond these designed intentions. Analysing the situation from the IV-stand's perspective we understand how affordances are always relational and the different affordances unfold in time (in flux). Waiting is disrupted because of the beeping IV-pump, in the waiting area the different materials are placed and people are seated in a particular manner because of the moving of the IV-stand, the conversation about the driver's license happens because the IV-pump has to be plugged into a wall outlet.

This third perspective shows the social and the material performing together in a concrete situation. It shows how affordances become available in a situation and how artifacts like an IV-stand are part of waiting practices. From this situated perspective an artifact like the IV-stand shows its ability to gather people around itself. It makes it possible for patients, caregivers and parents to meet each other. During waiting the IV-stand is not only just there nor is it only used for what it is designed, but it creates situations and makes caring (for) possible; it is not merely used as medical equipment (Mol et al., 2010). Finding a power source is interlaced with conversation about things like studying for a driver's license. Even when the children are not aware of or interested in the IV-stand, it is there and makes certain things possible - and others impossible. Because of the indeterminacy of practices, without the IV-stand the scene would probably have evolved differently: people would be sitting differently or the objects in the waiting area would be arranged differently.

\section{d. Closing the case study}

In this case study we explored the IV-stand as a gathering node in the hospital ward (for an overview, see Table 1). Unlike those who study the culturally and symbolically significant surfaces of objects (e.g., Prown, 1982), we studied how the IV-stand plays a part in the existence of ongoing material arrangements and practices (cf. Rinkinen, Jalas and Shove, 2015). We did this by analysing everyday practices through observations and videos made by two participants in a paediatric day-care ward and by looking for traces of the IV-stand in literature and daily encounters. Through this node it became possible to reveal how a 'thing' like the IV-stand has become deeply embedded in well-established care practices in Western society - as in the 'Gentse feesten'-example where it sets the scene for the viewers. Gradually zooming in, we 
illustrated how it is involved in all kinds of practices and, because of its proximity to bodies and movability, other practices and materials are foregrounded that would otherwise stay unnoticed. The third perspective from within an unfolding situation pointed at concrete doings of the IV-stand, how the social and the material are intertwined, and its ability to gather people and artifacts around itself.

The three perspectives are helpful to adopt a nuanced and, following Schatzki's (2002) notion of site ontology, situated approach to Gibson's (1979) notion of affordance. Care may be too broad as a site to understand the doings around the IV-stand, as may be waiting. The site, we would say, is 'waiting while receiving treatment': it helps to make sense of what is going on while at the same time the described affordances and practices form and are intrinsically part of the context. Waiting while receiving treatment would be very different without for example the IV-stand. The relational approach to spatiality, understanding practice-place-object relations as unfixed, offers ways to view space(s) in a more dynamic and undetermined way. The IV-stand affords leaning on, conversation, etc. - just as the hospital bed affords all kinds of things (see Fig. 3 and 4) - in relation to the other aspects of the material arrangements and practices it is situated in.

Table 1 -- Schematic overview of our analysis with the IV-stand as node

\begin{tabular}{|c|c|c|c|c|}
\hline IV-stand & Practices & $\begin{array}{c}\text { Material } \\
\text { arrangements }\end{array}$ & Place & Path \\
\hline Zoomed-out perspective & $\begin{array}{l}\text { - Part of medical care } \\
\text { practices since } 1950\end{array}$ & $\begin{array}{l}\text { - The hospital building } \\
\text { - Technologies of care } \\
\text { in a hospital setting } \\
\text { - Defines other objects } \\
\text { and people as related } \\
\text { to hospitals and care }\end{array}$ & $\begin{array}{l}\text { - To induce fluids } \\
\text { into human } \\
\text { bodies in a safe } \\
\text { and controlled } \\
\text { way }\end{array}$ & $\begin{array}{l}\text { - To receive } \\
\text { treatment } \\
\text { (become/feel } \\
\text { better) } \\
\text { - To be mobile } \\
\text { while receiving } \\
\text { treatment }\end{array}$ \\
\hline Observer's perspective & $\begin{array}{l}\text { Involved in: } \\
\text { - Medical care practices } \\
\text { - Bathroom practices } \\
\text { - Waiting practices } \\
\text { - Eating practices } \\
\text { - Play practices } \\
\text { - Being on a smartphone } \\
\text { - Celebrating practices } \\
\text { - Resting practices } \\
\text { - Video research practices } \\
\text { - ... }\end{array}$ & $\begin{array}{l}\text { - The material } \\
\text { infrastructure of the } \\
\text { day-care ward (walls, } \\
\text { doors, floors, } \\
\text { windows,...) } \\
\text { - Medical technologies } \\
\text { like alcohol gel } \\
\text { dispensers, isolation } \\
\text { gowns, blood pressure } \\
\text { monitors, but also } \\
\text { mundane things like a } \\
\text { bag of chips, a card } \\
\text { game, a piano, } \\
\text { magazines, laptops,... }\end{array}$ & $\begin{array}{l}\text { - To induce fluids } \\
\text { into human } \\
\text { bodies } \\
\text { - To have } \\
\text { conversations } \\
\text { - To lean and to } \\
\text { rest on } \\
\text { - To install } \\
\text { relations amongst } \\
\text { patients and staff, } \\
\text { other patients,... } \\
\text { - To... }\end{array}$ & $\begin{array}{l}\text { - To stand on } \\
\text { while moving to } \\
\text { Y from } X \text { in the } \\
\text { ward } \\
\text { - To ask for the } \\
\text { attention of a } \\
\text { nurse (when } \\
\text { beeping) } \\
\text { - To... }\end{array}$ \\
\hline $\begin{array}{l}\text { Within an unfolding situation: } \\
\text { 'waiting in the day-care ward' }\end{array}$ & $\begin{array}{l}\text { Things people do while } \\
\text { waiting: } \\
\text { - staring } \\
\text { - tying shoelaces } \\
\text { - reading } \\
\text { - talking } \\
\text { - moving about } \\
\text { - lifting feet } \\
\text { - listening to music } \\
\text { - doing nothing in particular } \\
\text { - texting } \\
\text {-... }\end{array}$ & $\begin{array}{l}\text { - The recognizable } \\
\text { waiting area: } \\
\text { (untouched) books and } \\
\text { informational leaflets, } \\
\text { a coat rack at the } \\
\text { entrance, a low table } \\
\text { in the middle with } \\
\text { colouring pages or } \\
\text { used magazines, wall } \\
\text { outlets, blue seats and } \\
\text { an orange wall with a } \\
\text { playful painting to } \\
\text { mark the space as } \\
\text { waiting area for } \\
\text { children,... }\end{array}$ & $\begin{array}{l}\text { - To have } \\
\text { conversations } \\
\text { about things as } \\
\text { obtaining a } \\
\text { driver's licence, } \\
\text { football,... } \\
\text { - To... }\end{array}$ & $\begin{array}{l}\text { - To move from } \\
\text { one seat in the } \\
\text { waiting area to } \\
\text { another seat to } \\
\text { be close to a } \\
\text { wall outlet } \\
\text { - To make time } \\
\text { to do other } \\
\text { things } \\
\text { - To... }\end{array}$ \\
\hline
\end{tabular}




\section{Discussion and concluding remarks}

In this article we studied everyday practices of children in a day-care hospital ward; understanding children as active constituents of the world and as situated in relation to everyday environments contributing to its making (cf. Hackett et al., 2015). To this end, we focused on how the children in our pilot study are part and carriers of mundane practices in the day-care ward. Foregrounding a thing like the IV-stand as gathering node allows, on the one hand, to see the complexity and diversity of ongoing everyday practices. On the other hand, it helps to direct attention to how the material and the social are always intertwined. Because of the proximity of the IV-stand to bodies, this perspective offers insights into the relationships between objects and human practices. The IV-stand does not dismiss or deny the perspective of the child. Rather to understand the perspective of the children (humans) we are asking a thing (cf. Giaccardi et al., 2016; see also Appadurai, 1986). By studying this thing as incorporated in practices, we learn about both people and objects at the same time. In different design fields a 'thing perspective' (Giaccardi et al., 2016, p. 235) is becoming increasingly important, as illustrated by the recent development of object personas (Cila et al., 2015). How these approaches can be used as a lens in the design of built care environments is yet to be explored.

In this article our first goal was to refine our conceptual and methodological framework to research children's spatiality in cancer care environments. In this respect, maybe the most important thing we have learned is not to hurry in research. Carefully untangling everyday doings, as we have tried to do in our case study, is too often skipped over in the race for results while they could have important things to say (cf. Horton and Kraftl, 2006). Conceptually, Schatzki's (2002) theory of practice and Gibson's (1979) theory of affordances offer a rich vocabulary and theoretical lens to explore spatiality through socio-material practices of and with children. Focusing on things (whether movable through space like an IV-stand or a card game; or immovable like a wall or a doorway) helps to acknowledge practices as shaping and part of space, foregrounds the contingency of the spatial, and situates these children not above but among objects.

This brings us to the second aim to offer another perspective on child-friendly care environments. Birch et al.'s (2007) search for the child-friendly hospital is ongoing and takes on many different forms. Design perspectives that go beyond child-friendly as childish or 'Disneyesque' (Mannion and I'Anson, 2004) emphasize how children's care environments should support individualisation, customisation, flexibility, sense of control, and autonomy (e.g., Birch et al., 2007; Verschoren et al., 2015). This categorical understanding of child-friendliness can be critiqued for being based on an individualist idea of personhood and carries the risk of othering young people (cf. Birch, 2018; Blaise, 2016). A socio-material perspective, as the one we started to unravel in this article, understands child-friendliness as a shared and mutual learning process between different (f)actors of which children are one; child-friendliness becomes meaningful - is done - only in a relation. To put it simply, child-friendliness can be viewed as 'a set of attributes and principles to guide [design] practice or it can be seen to emerge in the co-construction of care that takes place in and through particular care settings' (Bromley, 2012, p. 1065, on patientcenteredness). Our article shows the relevance of the latter view. By being attentive to everyday practices and materials we illustrated how care revolves around and in collision with mundane things like an IV-stand. Developing a relationship between a patient and a caregiver, a parent or another patient does not happen in therapy rooms alone or through well-targeted tactful actions, but also through plugging in an IV-pump affording conversation about a driver's license. For nurses and other care workers our research helps to acknowledge the role of these everyday human and other-than-human encounters as part of their care work but that has no place in a logic of efficiency.

Schatzki's notion of site makes it more difficult to locate child-friendliness in a particular space (the play room, at playful wall decorations, a room with more privacy, etc.), while at the same time inviting to look 
for moments and situations of (child-)friendliness in and around the hospital. For designers of the built environment our research suggests healthcare environments that balance and merge but not per se contrast technological care with child-friendly care (cf. Zitzelsberger et al., 2014). Hiding medical work/machinery, striving to be unlike a hospital, or integrating 'places for children' (Rasmussen, 2004, p. 155) do not by themselves make a hospital environment child-friendly or not. Designers could, instead, take everyday practices as a starting point (Pink, 2012; Shove et al., 2007) to involve children as more equal stakeholders in the design of healthcare environments. Maybe child-friendly design is design that recognizes (and allows a degree of) indeterminacy in the highly regulated and controlled environments and lives of children in the hospital - be it a hospital bed affording a stage for this child to practice playing the piano with the music therapist or that girl and her mother 'just' dragging and pushing an IV-stand doing nothing in particular.

Funding: This research received generous support from Kom op tegen Kanker

\section{Literature}

Adams, A., 2008. Medicine by design. The architect and the modern hospital, 1893-1943. University of Minnesota Press, Minneapolis.

Adams, A., 2017. Decoding modern hospitals: An architectural history. Architectural Design 87(2), 16-23.

Adams, A., Theodore, D., Goldenberg, E., McLaren, C., McKeever, P., 2010. Kids in the atrium: Comparing architectural intentions and children's experiences in a pediatric hospital lobby. Social Science \& Medicine 70(5), 658-667.

Adams, A., Theodore, D., McKeever, P., 2009. Pictures of health: Sick kids exposed. In: Lerner, L. (Ed.), Depicting Canada's children. Wilfrid Laurier University Press, Waterloo, pp. 259-278.

Änggård, E., 2016. How matter comes to matter in children's nature play: Posthumanist approaches and children's geographies. Children's Geographies 14(1), 77-90. Doi: 10.1080/14733285.2015.1004523.

Appadurai, A., 1986. Introduction: Commodities and the politics of value. In: Appadurai, A. (Ed.), The social life of things: Commodities in cultural perspective. Cambridge University Press, Cambridge, pp. 3-63.

Bates, V., 2018. 'Humanizing' healthcare environments: Architecture, art and design in modern hospitals. Design for Health 2(1), 5-19. Doi: 10.1080/24735132.2018.1436304.

Baumers, S., Heylighen, A., 2010, July. Beyond the designers' view: How people with autism experience space. In: Design and Complexity. Proceedings of the Design Research Soci4ety Conference 2010, Design Research Society.

Baxter, P., Jack, S., 2008. Qualitative case study methodology: Study design and implementation for novice researchers. The qualitative report 13(4), 544-559.

Birch, J., 2018. Museum spaces and experiences for children - ambiguity and uncertainty in defining the space, the child and the experience. Children's Geographies 16(5), 516-528. Doi: 10.1080/14733285.2018.1447088.

Birch, J., Curtis, P., James, A., 2007. Sense and sensibilities: In search of the child-friendly hospital. Built Environment 33(4), 405-416. Doi: 10.2148/benv.33.4.405. 
Bishop, K.G., 2009. Through children's eyes: Understanding how to create supportive healthcare environments for children and adolescents. World Health Design Journal, 61-67.

Bishop, K.G., 2010. Through the eyes of children and young people: The components of a supportive hospital environment. Neonatal, Paediatric and Child Health Nursing vol. 13, 17-25.

Blaise, M., 2016. Fabricated Childhoods: Uncanny encounters with the more-than-Human. Discourse: Studies in the Cultural Politics of Education 37(5), 617-626.

Bromley, E., 2012. Building patient-centeredness: Hospital design as an interpretive act. Social Science \& Medicine 75(6), 1057-1066.

Buse, C., Martin, D., Nettleton, S., 2018. Conceptualising 'materialities of care': Making visible mundane material culture in health and social care contexts. Sociology of Health \& Illness 40(2), 243-255. Doi: 10.1111/1467-9566.12663.

Caldwell, R., 2012. Reclaiming agency, recovering change? An exploration of the practice theory of Theodore Schatzki. Journal for the Theory of Social Behaviour 42(3), 283-303. Doi: 10.1111/j.14685914.2012.00490.x.

Chemero, A., 2003. An Outline of a Theory of Affordances. Ecological Psychology 15(2), 181-195. Doi: 10.1207/S15326969ECO1502_5.

Cila, N., Giaccardi, E., Tynan-O'Mahony, F., Speed, C., Caldwell, M., 2015. Thing-centered narratives: A study of object personas. Proceedings 3rd Seminar of the Research Network for Design Anthropology, January 22-23, Aarhus, Denmark.

Costall, A., 2012. Canonical affordances in context. Avant 3(2), 85-93.

Epstein, I., Stevens, B., McKeever, P., Baruchel, S., 2006. Photo elicitation interview (PEI): Using photos to elicit children's perspectives. International Journal of Qualitative Methods 5(3), 1-11. Doi: 10.1177/160940690600500301.

Fayard, A.L., Weeks, J., 2007. Photocopiers and water-coolers: The affordances of informal interaction. Organization studies 28(5), 605-634.

Flyvbjerg, B., 2006. Five misunderstandings about case-study research. Qualitative inquiry 12(2), 219-245.

Frank, A.W., 2015. The angel and the IV pump. Society 52(5), 469-474. Doi: 10.1007/s12115-015-9930-2.

Giaccardi, E., Speed, C., Cila, N., Caldwell, M., 2016. Things as co-ethnographers: Implications of a thing perspective for design and anthropology. In: Smith, R.C., Vangkilde, K.T., Kjærsgaard, M.G., Otto, T., Halse, J., Binder, T. (Eds.), Design Anthropology Futures. Bloomsbury, London, pp. 235-248.

Gibson, J.J., 1979. The ecological approach to visual perception. Houghton Mifflin Harcourt (HMH), Boston.

Hackett, A., Procter, L., Seymour, J., 2015. Introduction: Spatial perspectives and childhood studies. In: Seymour, J., Hackett, A., Procter, L. (Eds.), Children's Spatialities: Embodiment, emotion and agency. Palgrave Macmillan, London, pp. 1-17. 
Heath, G., Greenfield, S., Redwood, S., 2015. The meaning of 'place' in families' lived experiences of paediatric outpatient care in different settings: A descriptive phenomenological study. Health \& Place 31, 46-53. Doi: 10.1016/j.healthplace.2014.10.014.

Heinemann, L.L., 2015. Accommodating care: Transplant caregiving and the melding of health care with home life in the United States. Medicine Anthropology Theory|An Open-Access Journal in the Anthropology of Health, Illness, and Medicine 2(1), 32. Doi: 10.17157/mat.2.1.211.

Holloway, S.L., Valentine, G., 2000. Spatiality and the new social studies of childhood. Sociology 34(4), 763783.

Holloway, S.L., Holt, L., Mills, S., 2018. Questions of agency: Capacity, subjectivity, spatiality and temporality. Progress in Human Geography. Doi: 10.1177/0309132518757654.

Horton, J., Kraftl, P., 2006. What else? Some more ways of thinking and doing 'Children's Geographies'. Children's geographies 4(1), 69-95.

Ingold, T., 2000. The Perception of the Environment. Routledge, Abingdon.

James, A., Curtis, P. 2012. Constructing the Sick Child: The Cultural Politics of Children's Hospitals. The Sociological Review 60(4), 754-772. Doi: 10.1111/j.1467-954X.2012.02132.x.

Jarzabkowski, P., Pinch, T., 2013. Sociomateriality is 'the New Black': Accomplishing repurposing, reinscripting and repairing in context. M@n@gement 16(5), 579-592. Doi: 10.3917/mana.165.0579.

Kearns, R.A., Barnett, J.R., 2000. "Happy Meals" in the Starship Enterprise: Interpreting a moral geography of health care consumption. Health \& place 6(2), 81-93.

Koutamanis, A., 2006. Buildings and affordances. In: Gero, J.S. (Ed.), Design computing and cognition. Springer, Dordrecht, pp. 345-364.

Kozlovsky, R., 2013. The architectures of childhood. Children, modern architecture and the construction of postwar England. Ashgate Studies in Architecture.

Kozlovsky, R., 2015. Architecture, emotions and the history of childhood. In: Olsen, S. (ed.) Childhood, youth, emotions in modern history: National, Colonial and Global Perspectives. Palgrave MacMillan, pp. 95118.

Lambert, V., Coad, J., Hicks, P., Glacken, M., 2014a. Young children's perspectives of ideal physical design features for hospital-built environments. Journal of Child Health Care 18(1), 57-71. Doi: $10.1177 / 1367493512473852$.

Lambert, V., Coad, J., Hicks, P., Glacken, M., 2014b. Social spaces for young children in hospital: Social spaces children in hospital. Child: Care, Health and Development 40(2), 195-204. Doi: doi.org/10.1111/cch.12016.

Leder Mackley, K., Pink, S., Moroşanu, R., 2015. Knowing the world through your body: Children's sensory experiences and making of place. In: Seymour, J., Hackett, A., Procter, L. (Eds.), Children's spatialities: Embodiment, emotion and agency. Palgrave Macmillan, London, pp. 21-38. 
Lindberg, A., Lyytinen, K., 2013. Towards a theory of affordance ecologies. In: de Vaujany, F.-X., Mitev, N. (Eds.), Materiality and space. Palgrave Macmillan, London, pp. 41-61. Doi: 10.1057/9781137304094_3.

Lindberg, K., Walter, L., 2013. Objects-in-use and organizing in action nets: A case of an Infusion Pump. Journal of Management Inquiry 22(2), 212-227. Doi: 10.1177/1056492612455242.

MacRae, C., Hackett, A., Holmes, R., Jones, L., 2018. Vibrancy, repetition and movement: Posthuman theories for reconceptualising young children in museums. Children's Geographies 16(5), 503-515.

Maier, J.R., Fadel, G.M., 2009. Affordance based design: A relational theory for design. Research in Engineering Design 20(1), 13-27.

Malone, K., 2015. Theorizing a child-dog encounter in the slums of La Paz using post-humanistic approaches in order to disrupt universalisms in current 'child in nature' debates. Children's Geographies 14(4), 390-407. doi:10.1080/14733285.2015.1077369.

Mannion, G., I'Anson, J. 2004. Beyond the Disneyesque: Children's participation, spatiality and adult-child relations. Childhood 11(3), 303-318.

Merewether, J., 2019. New materialisms and children's outdoor environments: Murmurative diffractions. Children's Geographies 17(1), 105-117. Doi: 10.1080/14733285.2018.1471449.

Milstein, D., 2015. Constructing collaborative interpretations: Children as co-researchers in an ethnographic study in Argentina. In: Smeyers, P., Bridges, D., Burbules, N.C., Griffiths, M. (Eds.), International handbook of interpretation in educational research. Springer Netherlands, Dordrecht, pp. 529-549. Doi: 10.1007/978-94-017-9282-0_25.

Mol, A., 2008. I eat an apple. On theorizing subjectivities. Subjectivity 22(1), 28-37. Doi: 10.1057/sub.2008.2

Mol, A., Moser, I., Pols, J., (Eds.). 2010. Care in practice: On tinkering in clinics, homes and farms. TranscriptVerl, Bielefeld.

Nicolini, D., 2009. Zooming in and out: Studying practices by switching theoretical lenses and trailing connections. Organization Studies 30(12), 1391-1418. Doi: 10.1177/0170840609349875.

Noens, P., Ramaekers, S., 2015. The family as a "gathering": How the life of an object "makes" a family. International Journal of Child, Youth and Family Studies 5(4.2), 722-740.

Noens, P., Ramaekers, S., 2017. Gezin als pedagogische sit-uatie. In: Luyten, D., Van Crombrugge, H., Emmery, K. (Eds.) Het gezin in Vlaanderen 2.0. Over het eigene van gezinnen en gezinsbeleid. Antwerpen: Garant, pp. 183-196.

Norton-Westwood, D., 2012. The health-care environment through the eyes of a child-Does it soothe or provoke anxiety?. International Journal of Nursing Practice 18(1), 7-11.

Nuffield Foundation, 1963. Children in hospital: Studies in planning. Oxford University Press, London.

Overcash, J.A., 2003. Narrative research: A review of methodology and relevance to clinical practice. Critical Reviews in Oncology/Hematology 48(2), 179-184. Doi: 10.1016/j.critrevonc.2003.04.006.

Packer, M., 2011. The science of qualitative research. Cambridge University Press, Cambridge. 
Parbhu, N., Reay, S., Landhuis, E., Water, T., 2019. Differing perspectives: Evaluation of a new IV pole by children and adults. Journal of Child Health Care. Doi: 1367493518819221.

Peeters, K., Jellema, P., Annemans, M., Heylighen, A., 2018. How do adolescents affected by cancer experience a hospital environment? Journal of Adolescent and Young Adult Oncology 00(00), 1-5.

Pink, S., 2012. Situating everyday life: Practices and places. Sage, London.

Pink, S., 2013. Doing visual ethnography. Sage, London.

Preda, A., 1999. The turn to things: Arguments for a sociological theory of things. The sociological quarterly 40(2), 347-366.

Prior, L., 1988. The architecture of the hospital: A study of spatial organization and medical knowledge. The British Journal of Sociology 39(1), 86-113.

Prown, J.D., 1982. Mind in matter: An introduction to material culture theory and method. Winterthur portfolio 17(1), 1-19.

Rasmussen, K., 2004. Places for children-children's places. Childhood 11(2), 155-173.

Rautio, P., 2013. Children who carry stones in their pockets: On autotelic material practices in everyday life. Children's Geographies 11(4), 394-408. Doi: 10.1080/14733285.2013.812278.

Reed, E.S., 1996. Encountering the world: Toward an ecological psychology. Oxford University Press, Oxford.

Reh, S., Temel, R., 2014. Observing the doings of built spaces. Attempts of an ethnography of materiality. Historical Social Research/Historische Sozialforschung 39(2), 167-180.

Rietveld, E., Kiverstein, J., 2014. A Rich landscape of affordances. Ecological Psychology 26(4), 325-352. Doi: 10.1080/10407413.2014.958035.

Rietveld, E., Rietveld, R., 2011. The paradox of spontaneity and design: Designing spontaneous interactions, Oase 85, 33-41.

Rinkinen, J., Jalas, M., Shove, E., 2015. Object relations in accounts of everyday life. Sociology 49(5), 870885. Doi: 10.1177/0038038515577910.

Schatzki, T.R., 1991. Spatial ontology and explanation. Annals of the Association of American Geographers 81(4), 650-670.

Schatzki, T.R., 2002. The site of the social: A philosophical account of the constitution of social life and change. Penn State Press, Pennsylvania.

Schatzki, T.R., 2009. Timespace and the organization of social life. In: Shove, E., Trentmann, F., Wilk, R. (Eds.), Time, consumption and everyday life: Practice, materiality and culture. Berg, New York, pp. 35-48.

Schatzki, T.R., 2012. A primer on practices. In: Higgs, J., Barnett, R., Billett, S., Hutchings, M., Trede, F. (Eds.), Practice-based education. Sense Publishers, Rotterdam, pp. 13-26.

Shove, E., Watson, M., Hand, M., Ingram, J., 2007. The design of everyday life. Berg, Oxford. 
Sloane, D.C., 2008. A (better) home away from home. The emergence of children's hospitals in an age of woman's reform. In: Guttman, M., De Coninck-Smith, N. (Ed.), History, space and the material culture of children, London: Rutgers University Press, pp. 42-60.

Southorn, P.A., Narr, B.J., 2008. The Massa or Rochester plastic needle. Mayo Clinic Proceedings 83(10), 1165-1167. Doi: 10.4065/83.10.1165.

Tutenel P., Ramaekers S., Heylighen A., 2019. Conversations between procedural and situated ethics: Learning from video research with children in a cancer care ward. The Design Journal 22 (sup1), 641-654.

Van der Horst, F.C., Van Der Veer, R., 2009. Changing attitudes towards the care of children in hospital: A new assessment of the influence of the work of Bowlby and Robertson in the UK, 1940-1970. Attachment \& Human Development 11(2), 119-142. Doi: 10.1080/14616730802503655.

van Dijk, L., Rietveld, E., 2017. Foregrounding sociomaterial practice in our understanding of affordances: The Skilled Intentionality Framework. Frontiers in Psychology 7. Doi: 10.3389/fpsyg.2016.01969.

Van Eron-Sherman, K., 2009. A night in the hospital: A patient's view. Ergonomics in Design: The Quarterly of Human Factors Applications 17(2), 11-14. Doi: 10.1518/106480409X435952.

Verschoren, L., Annemans, M., Van Steenwinkel, I., Heylighen, A., 2015. Designing child-sized hospital architecture: Beyond preferences for colours and themes. In: Proceedings of the 20th ICED15. Politecnico di Milano, Italy.

Walker, B.L., 2018. A family history of illness: Memory as medicine. University of Washington Press, Seattle.

Water, T., Wrapson, J., Reay, S., Ford, K., 2018. Making space work: Staff socio-spatial practices in a paediatric outpatient department. Health \& Place 50, 146-153. Doi: 10.1016/j.healthplace.2018.01.007.

Water, T., Wrapson, J., Tokolahi, E., Payam, S., Reay, S., 2017. Participatory art-based research with children to gain their perspectives on designing healthcare environments. Contemporary Nurse 53(4), 456-473. Doi: 10.1080/10376178.2017.1339566.

Wilson, S., Houmøller, K., Bernays, S., 2012. Home, and not some house: Young people's sensory construction of family relationships in domestic spaces, Children's Geographies 10(1), 95-107.

Woodyer, T., 2008. The body as research tool: Embodied practice and children's geographies. Children's Geographies 6, 349-362.

Yin, R.K., 2011. Applications of case study research. Sage, London.

Zitzelsberger, H., McKeever, P., Chambon, A., Morgan, K.P., Spalding, K., 2014. Doing 'technological time' in a pediatric hemodialysis unit: An ethnography of children. Health \& Place 27, 112-119. Doi: 10.1016/j.healthplace.2014.02.007. 